as informed me that to his knowledge here have been no additional reports this species in Alberta. The reeding range is northwestern British olumbia, Yukon, Alaska and robably Siberia.

It is, therefore, of interest to record lat on September 2, 1973, I had good lews of four tattlers accompanied by vo Pectoral Sandpipers on the south hore of Beaverhill Lake, about 40 iles east of Edmonton. Observation prough 10-power binoculars showed he tatiler to be considerably larger han the sandpiper. They were grey oove and white below though one of hem still showed faint dark bars on he side of the breast. They had black eaks and greenish legs and in flight howed no wing bars or white arkings on rump or tail.

These four birds not only represent e largest number of their species so $r$ seen at one time in Alberta, but ey were also observed further east, e. further from the main route of igration of the species, than those eviously reported.

Department of Physiology,

hiversity of Albertit,

fimonton. Albertat.

AI,T, W. R. and WII.K, A. L., 1966. The birds of Alherta. 2nd Ed. Dept. Ind. and Dev., Edmonton. Alherta. $511 \mathrm{pp}$.

\section{PRAIRIE NEST RECORDS SCHEME}

Cards and information for the 1974 nesting season are available rom:

Prairie Nest Records Scheme, c/o Manitoba Museum of Man and Nature,

190 Rupert Ave., Winnipeg, Manitoba. R3B ONZ

A summary for the 1973 season is ivailable on request. More paricipants are required throughout he Prairic Provinces

H. W. R. Copland, Coordinator.

\section{DANCING SHARP-TAILED GROUSE AND PREDATORS}

by DALE HJERTAAS*

In the spring of 1973, while censusing Sharp-tailed Grouse dancing grounds with Saskatchewan Department of Natural Resources field crews, I noted several cases of predation and attempted predation.

On May 3, at Hafford Community Pasture, 8 miles south of Hafford, George Duff and I surprised a Goshawk feeding on a dead grouse in the middle of a dancing ground. The Goshawk carried the grouse toward the nearest trees, $1 / 4$ mile away, but dropped it half way. We recovered the grouse and later photographed it to show the partly eaten right breast.

The next day at the same dancing ground we observed a male Marsh Hawk harrassing grouse. Five times, it chased all 20 or so sharp-tails off the dancing ground but did not have the speed to capture a flying sharp-tail. Each time the grouse flew 40 or 50 yards, landed and almost immediately ran back part way; most then flew the remaining distance to the dancing ground.

On May 16, near Redvers, I observed another case of apparent attempted predation on courting sharp-tails. My view of this dancing was obscured by tall grass and weeds, although I could hear grouse dancing and calling vigorously. I observed individual birds flushing, flying about 10 or 15 feet and then landing. When I approached to count them, I caught a glimpse of a mammal disappearing into the weeds on the far side of the dancing ground. Its size, shape and slow speed, as indicated by moving grass, convinced me that it was a skunk, and that the unusual flushing by single sharp-tails was caused by this skunk endeavouring to capture a bird. The individual grouse flushed when approached closely, but were not frightened enough to leave. This reac-

*1118 Colony St..

Siskatomn, Sitskattehewatr. 
tion is similar to that reported by Rogers" when a deer was seen playing with Sharp-tailed Grouse in Colorado, striking at them with head and feet. These grouse merely moved a short distance and resumed dancing.

Sharp-tailed Grouse, when absorbed in the dance, are easy prey to coyotes according to Bent ${ }^{3}$. Rogers ${ }^{2}$ says that few things distract dancing Sharptailed Grouse. He reports six ravens, four ducks and two hawks spending an entire morning watching dancing grouse in Colorado. The hawks occasionally disrupted activity by swooping at the birds. When a coyote watched dancing sharp-tails, the grouse paid little attention to the intruder.

Predation on dancing Sharp-tailed Grouse is noted most years by DNR personnel. Wayne Pepper' has found remains of five banded and other unbanded grouse, apparently killed by predators, all within 300 yards of dancing grounds near Asquith. This is supporting evidence that predation at dancing grounds is not uncommon.

I wish to thank Wayne Pepper and Dr. C. Stuart Houston for their help with this article.

'BENT, E. C. 1963. Life histories of North American gallinaceous hirds. Dover Publications Inc., N.Y.

"PEPPER, G. W. 1972. The ecology of Sharp-tailed Grouse during spring and surnmer in the aspen parklands of Saskatchewan. Saskatchewan Dept. Nat. Res. Wildl. Rep. No. 1, 55 pp.

"ROGERS, G. E. 1967. The Sharp-tailed Grouse in Colorado. Colorado Dept. Nat. Res. Tech. Pub. 23, $94 \mathrm{pp}$.

\section{PINE SISKINS NESTING AT MOOSE JAW}

\section{by EDITH KERN*}

Bird-watchers of the Moose Jaw Natural History Society were quite excited to have found two known Pine Siskin nests in the city in the spring of 1973. One nest, well hidden, was

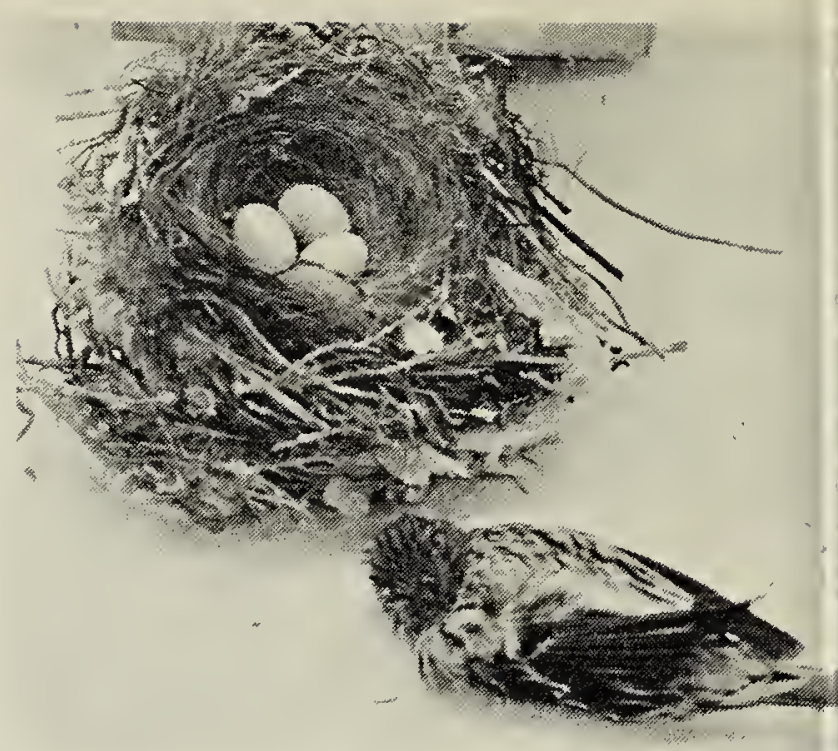

Pine Siskin and nest. Regina Leader-Po

found about 5 or 6 feet up in a spru tree at the Ken Bidwell home near th centre of the city. The Bidwell fami had seen the birds around for 2 or weeks in March and, after realizir they were probably nesting, kept clos watch for about 10 days. On April they decided that the nest had be deserted, and on April 6 removed tl nest which had three eggs in it. $c$ April 7 they found the dead fema Pine Siskin. They then informe Leith Knight, president of MJNH who suggested that the nest and skin turned over to the Saskatchew: Museum of Natural History. Fre Lahrman has since informed us th the eggs were "very heavily i cubated."

The second nest was in a taller tre several blocks northwest of the fii nest-site, and was active until abo May 2, when all activity ceased an the birds disappeared. Cats a thought to be the cause. The nest $w$ too high up to be retrieved.

As of May 12 there were numero flocks of 8 to 15 Pine Siskins coming daily to feeders (sunflower seed) other areas of the city but no oth nests were discovered. Also, Eveni Grosbeaks (adult male and femal and immature Red Crossbills (ma and female) were still coming in da to feeders (sunflower seed) in seves areas of the city.

*1086 Alder Ave.,

Moose Jaw, Saskatchewan.

S6H OY 4 